Бочарніков В. П., д.т.н., професор (ORCID: 0000-0003-4398-5551);

Центр воєнно-стратегічних досліджень Національного університету оборони України імені Івана Черняховського, Київ

\title{
Частотно-часовий аналіз сигналів на основі функцій поведінки і арифметичних рядів: дослідження працездатності методу
}

Резюме. У статті розглядаються результати досліджень працездатності нового методу частотночасового аналізу дискретних сигналів, які представлені часовими рядами. Для оціновання розглядається модельний сигнал, який сформований у вигляді суми синусоїдальних функцій 3 відомими частотами. Унаслідок використання методу отримуються оцінки спектра. Оцінюється точність отриманих оцінок спектра та точність відновлення сигналу на основі цього спектра для модельного сигналу. Наведені висновки та рекомендації щодо застосування методу для частотно-часового аналізу сигналів.

Ключові слова: часовий ряд; частотно-часовий аналіз; р-адичні числа; функції поведінки систем; системний аналіз; ідентифікація; арифметичні ряди; частотні спектри.

Вступ. Стаття $є$ продовженням розгляду нового методу частотно-часового аналізу часових рядів на основі функцій поведінки і арифметичних рядів. У праці [1] докладно надаються основні етапи розв'язання задачі оцінювання спектра сигналу.

1. Сигнал, що досліджується, представляється у вигляді часового ряду. Значення часового ряду визначаються в базисі $p$-адичних чисел [2], що дає змогу розглядати часовий ряд у вигляді системи даних для подальшого дослідження [3].

2. На основі отриманої системи даних формується множина функцій поведінки метасистеми. Ідентифікація метасистеми здійснюється на основі зміни значення показника породжуючої нечіткості системи [4].

3. Функція процедури зміни [5] метасистеми використовується для побудови імпульсної функції, яка моделює вхідний сигнал.

4. На основі вирішення рівнянь балансу для кожного імпульсу функції, яка моделює вхідний сигнал, формується оцінка поточного (миттєвого) спектра сигналу [1].

5. Для зниження впливу збурень, що знижують точність оцінювання спектра, використовується нечіткий дискретний фільтр $[6,7]$.

Таким чином запропонований метод дозволяє отримати оцінку спектру сигналу в тому числі для нестаціонарних сигналів. Цей спектр надає можливість відновити вхідний сигнал.

Мета роботи. Провести дослідження працездатності методу частотно-часового аналізу часових рядів на основі функцій поведінки і арифметичних рядів та оцінити можливі похибки оцінки спектру та відновленого сигналу на основі аналізу використання запропонованого методу для модельного сигналу, який сформований у вигляді суми синусоїдальних функцій.

Виклад основного матеріалу.

Вихідні дані, припущення та обмеження дослідження методу. Визначимо вихідні дані, припущення та обмеження для проведення дослідження працездатності методу. Для обгрунтування працездатності запропонованого методу частотно-часового аналізу часових рядів необхідно розв'язати дві взаємопов'язані класичні задачі. 3 одного боку маємо отримати спектр сигналу максимально близький до спектра реального сигналу, а 3 іншого боку мати можливість відновити початковий сигнал 3 максимальною точністю. Таким чином, сформулюємо часткові завдання дослідження.

1. Визначити спектр досліджуваного сигналу на основі оптимізаційного i наближеного підходів до оцінювання коефіцієнтів спектрального розкладання. Порівняти отримані результати 3 ідеальним спектром сигналу. Оцінити похибки визначення спектра.

2. На основі отриманих спектрів відновити вихідний часовий ряд. Оцінити похибки відновлення. Порівняти оптимізаційний і наближений підходи.

За критерій оцінки помилки, як спектрів, так i відновлених часових рядів використовуватимо функціонал відстані Хеммінга [8], нормованого в одиничному інтервалі. Для вирішення поставлених завдань введемо ряд припущень i обмежень. Для дослідження приймемо, що інтервал дискретизації сигналу становить 0,1 с. Час 
спостереження сигналу $W=10 \mathrm{c}$. Вихідний сигналів $f_{n}^{1}$ і $f_{n}^{2}$ з одиничними амплітудами і часовий ряд $\varphi_{n}$ розглядається як дискретне представлення суми двох синусоїдальних

круговими частотами 2,8 і 2,1 відповідно. Графіки часових рядів наведено на рис. 1.

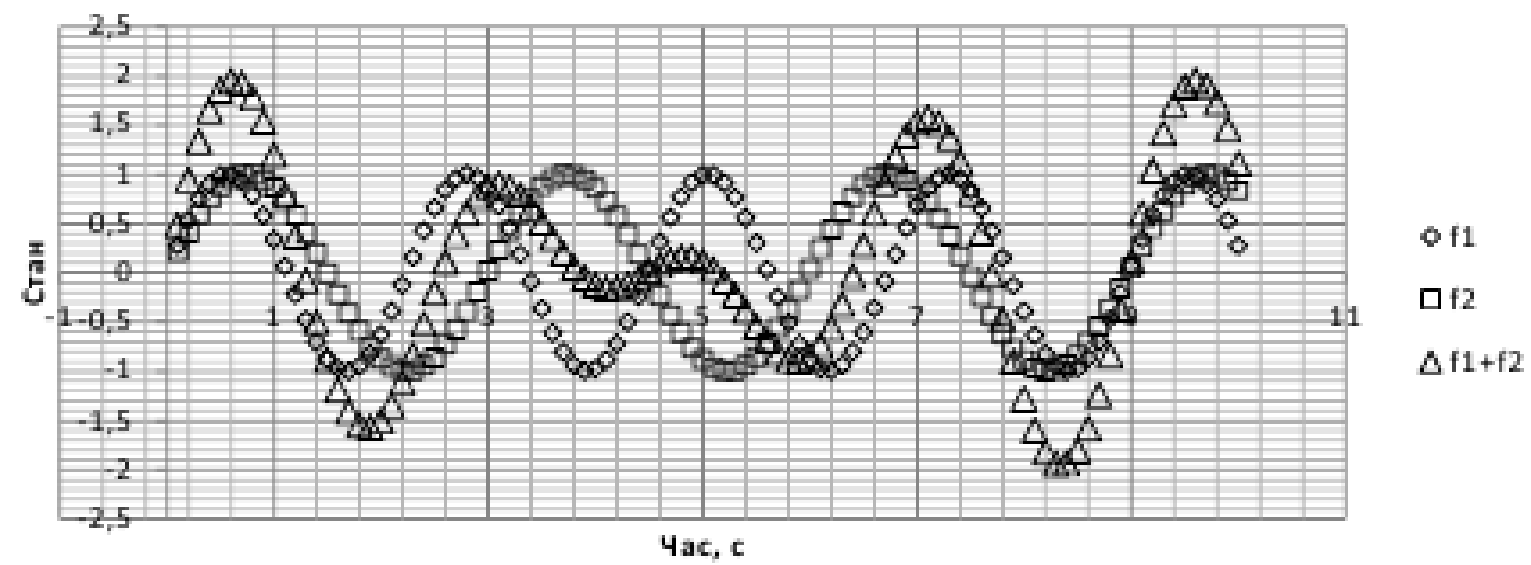

Рис. 1. Досліджуваний часовий ряд і синусоїдальні часові ряди, які його породжують

Як множина функцій розкладання $f_{n}^{2}$, породжують досліджуваний часовий ряд розглядаються чотири функції імпульсних синусів $\Phi=\left\{s i_{k}(t)\right\}, k=\overline{1,4}$, дві 3 яких відповідають синусоїдальним функціям $f_{n}^{1}$ i $\varphi_{n}$. Множина базисних функцій імпульсних синусів має вигляд

$$
\Phi=\left\{s i_{1}(t \mid 0 ; 15) ; s i_{2}(t \mid 0 ; 11) ; s i_{3}(t \mid 0 ; 20) ; s i_{4}(t \mid 0 ; 5) ;\right\} .
$$

Будемо вважати, що квантування за рівнем досліджуваного сигналу забезпечує потужність множини значень сигналу $\operatorname{Card}\left(Z_{t s}\right)=128$. Для представлення значення сигналу будемо використовувати $p$ адичні числа 3 s $p=2$. Для визначення множини вибіркових змінних і побудови

функції поведінки системи використовуватимо найпростішу маску з параметром зсуву $\rho=0$ для всіх змінних системи $v_{i, r_{k}(t)} \in V_{i}$. В алгоритмі ідентифікації метасистеми множина значень порогів відсікання $\left\{\Delta_{u}\right\}$ наведена в табл. 1.

Таблиця 1

Множина значень порогів відсікання прийнятих під час дослідження

\begin{tabular}{rl|c|c|c|c|c|c|c|c|c|c|c|}
\hline$u$ & 1 & 2 & 3 & 4 & 5 & 6 & 7 & 8 & 9 & 10 & 11 \\
\hline$\Delta_{u}$ & 0.23 & 0.225 & 0.22 & 0.215 & 0.21 & 0.205 & 0.2 & 0.195 & 0.19 & 0.185 & 0.18 \\
\hline
\end{tabular}

використовуватимо симетричне вікно $L R_{n}$ для досліджуваного часового ряду була 3 усередненою величиною відхилення $\varepsilon(n)=0.5 \times\left(\varepsilon_{L}(n)+\varepsilon_{R}(n)\right)$.

Результати дослідження. Дослідження запропонованого методу показали такі результати: на основі застосування підходу 3

Таблиця 2

Фрагмент матриці даних для досліджуваного часового ряду

\begin{tabular}{|l|c|c|c|c|c|c|c|c|c|c|}
\hline$t$ & 0.1 & 0.2 & 0.3 & 0.4 & 0.5 & 0.6 & 0.7 & 0.8 & 0.9 & 1 \\
\hline$v_{1}$ & 1 & 1 & 1 & 1 & 1 & 1 & 1 & 1 & 1 & 1 \\
\hline$v_{2}$ & 0 & 0 & 1 & 1 & 1 & 1 & 1 & 1 & 1 & 1 \\
\hline$v_{3}$ & 1 & 1 & 0 & 1 & 1 & 1 & 1 & 1 & 1 & 0 \\
\hline$v_{4}$ & 0 & 1 & 1 & 0 & 1 & 1 & 1 & 1 & 0 & 0 \\
\hline$v_{5}$ & 0 & 1 & 0 & 1 & 1 & 1 & 1 & 0 & 0 & 1 \\
\hline$v_{6}$ & 0 & 1 & 1 & 0 & 0 & 1 & 1 & 0 & 1 & 1 \\
\hline$v_{7}$ & 0 & 0 & 1 & 1 & 0 & 1 & 0 & 1 & 0 & 1 \\
\hline
\end{tabular}


Унаслідок використання алгоритму (рис. 2). На підставі цієї функції була отримана ідентифікації метасистеми була отримана узагальнена імпульсна функція $g(t)$ (рис. 3). повна двомірна імпульсна функція $r(u, t)$

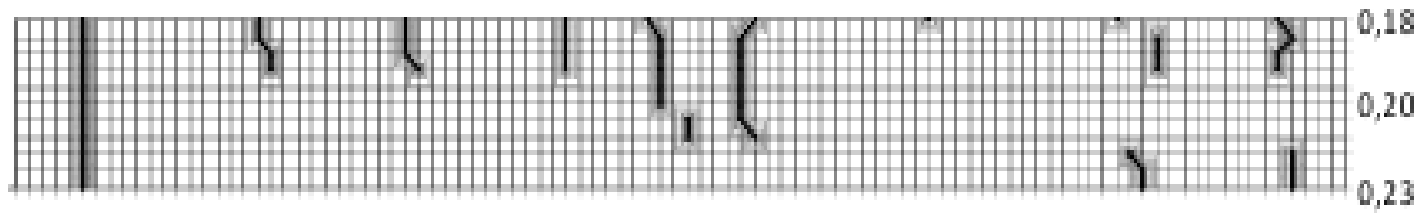

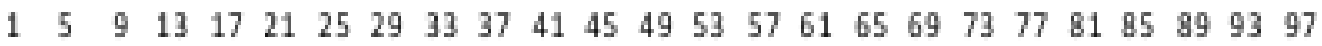

Рис. 2. Повна двомірна імпульсна функція $r(u, t)$ для досліджуваного часового ряду

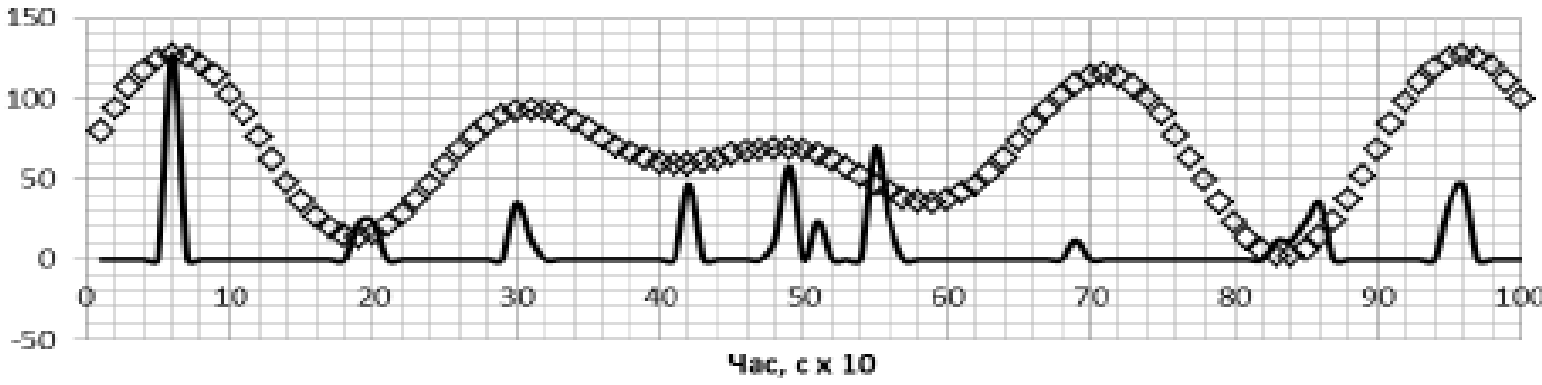

Рис. 3. Досліджуваний часовий ряд і відповідна йому узагальнена імпульсна функція $g(t)$ (нормована до максимального значення досліджуваного ряду)

Функція $g(t)$ дає змогу отримати $\tau_{n}$ визначалися як координати локальних імпульсну функцію досліджуваного часового екстремумів ряду $r\left(\tau_{n}\right)$. До того ж координати імпульсів

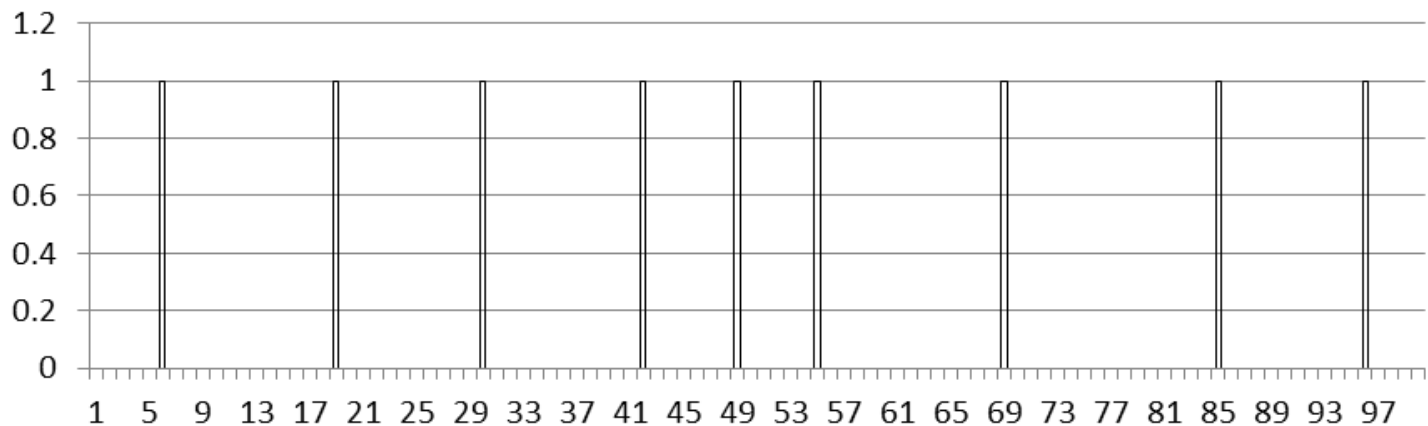

Рис. 4. Імпульсна функція досліджуваного часового ряду $r\left(\tau_{n}\right)$

На підставі отриманої імпульсної рівняння балансу для всіх $\tau_{n}, n=\overline{1, N}$. функції 3 використанням виразу для координати $\tau_{n}$ і заданої множини імпульсних функцій $\Phi=\left\{s i_{k}(t)\right\}, k=\overline{1,4}$ були отримані

Наприклад, для координати $\tau_{2}=19$ для усередненої величини відхилення вікно визначатиметься як:

$$
\begin{aligned}
L R_{n}=\left[\tau_{2}-0.25 \times\left(\tau_{3}-\tau_{1}\right) ; \tau_{2}+0.25 \times\left(\tau_{3}-\tau_{1}\right)\right]= \\
=[19-0.25 \times(30-6) ; 19+0.25 \times(30-6)]=[13 ; 25] \subseteq W .
\end{aligned}
$$

У цьому разі значення часткових сум будуть: $S_{1}\left(L R_{2}\right)=-21, S_{2}\left(L R_{2}\right)=-17, S_{3}\left(L R_{2}\right)=0, S_{4}\left(L R_{2}\right)=-5$, а коефіцієнти $\beta_{k}$ приймуть значення: $\quad \beta_{1}=(-1)^{2-1}=-1, \beta_{2}=-1, \beta_{3}=0, \beta_{4}=(-1)^{3-1}-(-1)^{4-1}=0$. $\quad$ Тоді рівняння балансу набуде вигляду:

$$
\frac{-21 \cdot x_{1}-17 \cdot x_{2}+0 \cdot x_{3}-5 \cdot x_{4}}{-x_{1}-x_{2}}=19 \Rightarrow 2 \cdot x_{1}-2 \cdot x_{2}+5 \cdot x_{4}=0 \text {. }
$$

Аналогічним чином формуються рівняння балансу для всіх координат. У табл. 3 наведені коефіцієнти рівнянь балансу (нев'язкі
$\left.\Lambda_{k}, k=\overline{1,4}\right)$ для отриманої послідовності координат імпульсів. 
Таблиця 3

Коефіціснти рівнянь балансу

\begin{tabular}{|c|c|c|c|c|}
\hline$\tau_{n}$ & $\Lambda_{1}$ & $\Lambda_{2}$ & $\Lambda_{3}$ & $\Lambda_{4}$ \\
\hline 19 & 2 & -2 & - & 5 \\
\hline 30 & - & 2 & -4 & 5 \\
\hline 42 & - & -3 & 4 & -5 \\
\hline 49 & 2 & -1 & 3 & 5 \\
\hline 55 & -4 & 5 & -5 & - \\
\hline 69 & 3 & -3 & -3 & -2 \\
\hline 86 & -5 & -3 & 1 & -4 \\
\hline
\end{tabular}

Для врахування похибок у визначенні імпульсної функції під час визначення значень коефіцієнтів $x_{k} \in[0,1]$, що входять у рівняння балансу, необхідне застосування наближених підходів, описаних вище. Для дослідження методу частотно-часового аналізу використовуємо підхід на основі лінійної оптимізації та прямий наближений метод оцінювання коефіцієнтів із подальшою фільтрацією.

У табл. 4а наведено оцінки коефіцієнтів $x_{k}$ (нормованого спектра сигналу) під час розв'язання оптимізаційної задачі лінійного програмування симплекс методом для координат ряду $\tau_{n}=\overline{1, N}$. У табл. 46 наведені оцінки коефіцієнтів $x_{k}$ після нечіткої фільтрації з коефіцієнтом посилення фільтра $\alpha=0.02$.

Таблиця 4

Оцінки коефіціснтів $\mathrm{x}_{\mathrm{k}}$ спектра сигналу, які отримані на основі оптимізації

\begin{tabular}{|c|c|c|c|c|}
\hline$\tau_{n}$ & $x_{4}$ & $x_{2}$ & $x_{1}$ & $x_{3}$ \\
\hline 19 & 0.000 & 0.500 & 0.500 & 0.000 \\
\hline 30 & 0.000 & 0.666 & 0.000 & 0.333 \\
\hline 42 & 0.000 & 1.000 & 0.000 & 0.000 \\
\hline 49 & 0.000 & 0.666 & 0.333 & 0.000 \\
\hline 55 & 0.000 & 0.444 & 0.555 & 0.000 \\
\hline 69 & 0.000 & 0.500 & 0.500 & 0.000 \\
\hline 86 & 0.000 & 0.250 & 0.000 & 0.750 \\
\hline
\end{tabular}

Табл. 4a

\begin{tabular}{|c|c|c|c|c|}
\hline$\tau_{n}$ & $x_{4}$ & $x_{2}$ & $x_{1}$ & $x_{3}$ \\
\hline 19 & 0.000 & 0.500 & 0.500 & 0.000 \\
\hline 30 & 0.000 & 0.503 & 0.490 & 0.007 \\
\hline 42 & 0.000 & 0.513 & 0.480 & 0.007 \\
\hline 49 & 0.000 & 0.516 & 0.477 & 0.006 \\
\hline 55 & 0.000 & 0.515 & 0.479 & 0.006 \\
\hline 69 & 0.000 & 0.515 & 0.479 & 0.006 \\
\hline 86 & 0.000 & 0.509 & 0.470 & 0.021 \\
\hline
\end{tabular}

Табл. 4 б

На рис. 5 наведені графіки оціненого спектру сигналу та ідеального спектра цього сигналу.
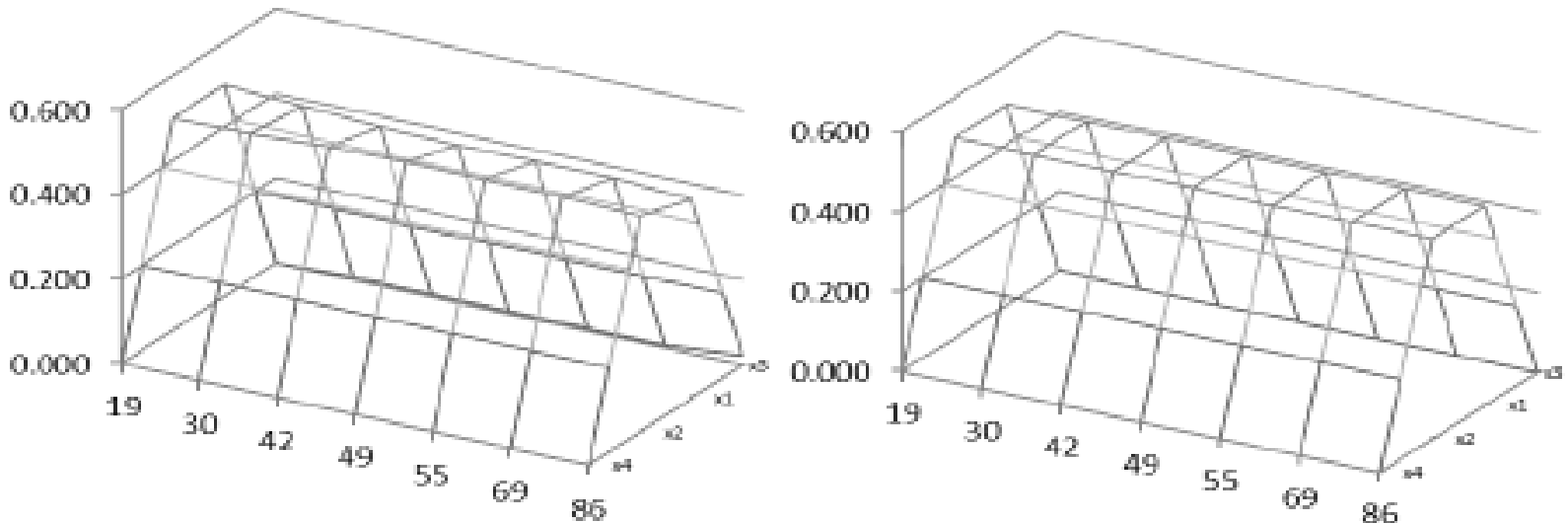

Рис. 5. Графіки оціненого спектра сигналу після фільтрації (ліворуч) та ідеального спектра цього сигналу (праворуч)

Середня помилка оцінки спектра по відстані Хеммінга становить 0,00891 або $0,89 \%$. На інтервалі $W=10 c$ максимальна помилка у відсотках становить 1,52\%. Слід зазначити, що помилки для нефільтрованих оціночних спектрів істотно вище. У середньому в цьому разі помилки складають до $12 \%$. Отже застосування фільтрації $\epsilon$ доцільним. Для стаціонарних сигналів коефіцієнт посилення фільтра може мати невеликі значення. У разі значної нестаціонарності сигналу доцільно коефіцієнт посилення збільшувати.
У табл. 5 наведено оцінки коефіцієнтів $x_{k}$ (нормованого спектра сигналу) у разі використання прямого наближеного підходу до їх визначення. У табл. 5а наведені безпосередньо отримані оцінки коефіцієнтів $x_{k}$, а в табл. 5б оцінки коефіцієнтів $x_{k}$ після фільтрації 3 коефіцієнтом посилення $\alpha=0.02$.

Середня помилка оцінки спектра по відстані Хеммінга становить 0,00966 або 0,97\%. Максимальна помилка на всьому інтервалі часу складає 1,71\%. Середня помилка для не 
фільтрованих оціночних спектрів становить до спектри в порівнянні з реальним спектром.

$14 \%$. На рис. 6 наведено отримані оціночні

Таблиця 5

Оцінки коефіціснтів $x_{k}$ спектра сигналу, які отримані прямим наближеним методом

\begin{tabular}{|c|c|c|c|c|}
\hline$\tau_{n}$ & $x_{4}$ & $x_{2}$ & $x_{1}$ & $x_{3}$ \\
\hline 19 & 0.000 & 0.500 & 0.500 & 0.000 \\
\hline 30 & 0.000 & 0.643 & 0.000 & 0.357 \\
\hline 42 & 0.000 & 1.000 & 0.000 & 0.000 \\
\hline 49 & 0.000 & 0.667 & 0.333 & 0.000 \\
\hline 55 & 0.000 & 0.474 & 0.526 & 0.000 \\
\hline 69 & 0.294 & 0.235 & 0.235 & 0.235 \\
\hline 86 & 0.182 & 0.273 & 0.091 & 0.455 \\
\hline
\end{tabular}

\begin{tabular}{|c|c|c|c|c|}
\hline$\tau_{n}$ & $x_{4}$ & $x_{2}$ & $x_{1}$ & $x_{3}$ \\
\hline 19 & 0.000 & 0.500 & 0.500 & 0.000 \\
\hline 30 & 0.000 & 0.503 & 0.490 & 0.007 \\
\hline 42 & 0.000 & 0.513 & 0.480 & 0.007 \\
\hline 49 & 0.000 & 0.516 & 0.477 & 0.007 \\
\hline 55 & 0.000 & 0.515 & 0.478 & 0.007 \\
\hline 69 & 0.006 & 0.509 & 0.473 & 0.011 \\
\hline 86 & 0.009 & 0.505 & 0.466 & 0.020 \\
\hline
\end{tabular}

Табл. 5а

Табл. 5 б

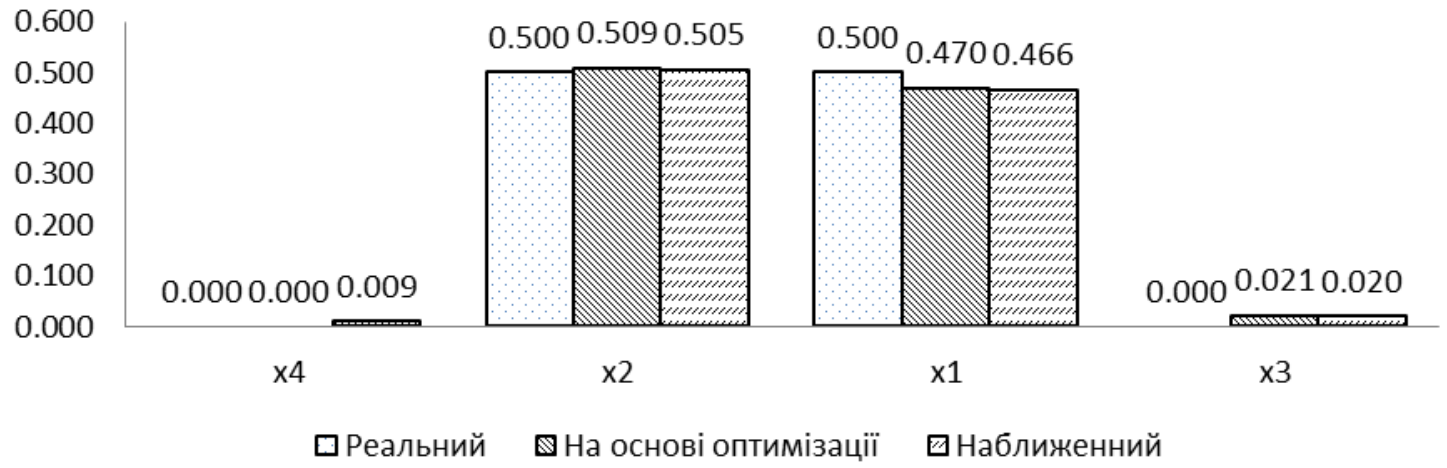

Рис. 6. Реальний спектр і оціночні спектри, що отримані різними підходами

Таким чином, запропоновані підходи до визначення спектра сигналу для модельного прикладу показали хорошу точність. Загалом похибка оцінки спектра не перевищує 1,8 \%. На підставі отриманих спектрів $є$ можливість відновлення сигналу. На рис. 7 наведено фрагмент часового ряду на інтервалі $[3,6] \subseteq W$, де спостерігається максимальна помилка відновлення числового ряду.

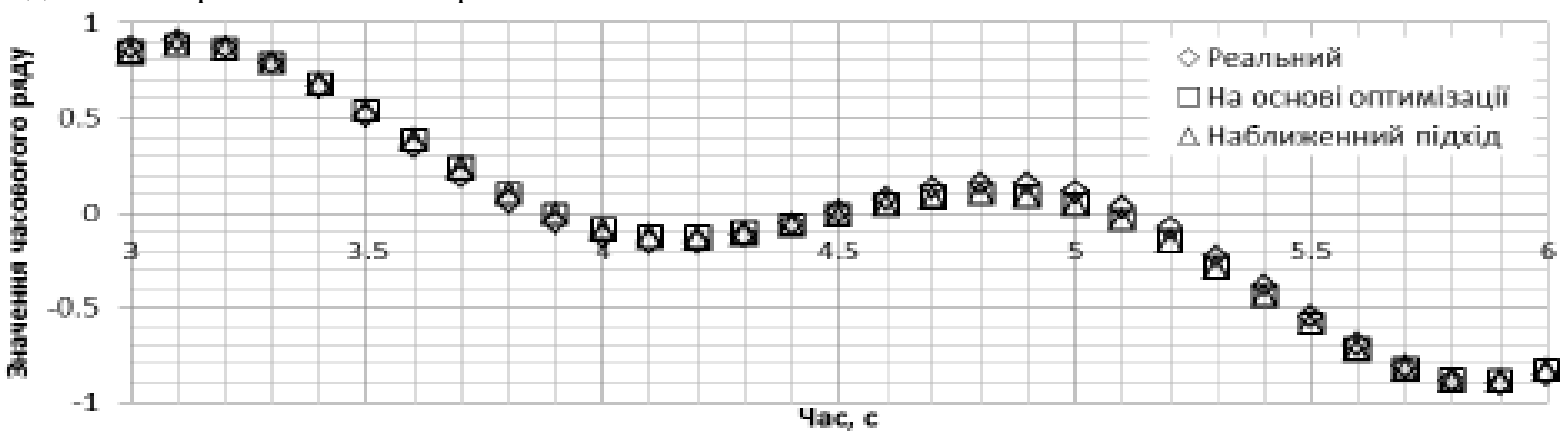

Рис. 7. Реальний і відновлені часові ряди на інтервалі $[3,6] \subseteq W$

На рис. 8 наведені графіки помилки часових рядів, відновлених на основі отриманих за допомогою запропонованого методу спектрів.

Як видно з графіків максимальна помилка відновлення вихідного часового ряду не перевищує 3,5\% (абсолютна помилка 0.07 при максимальній амплітуді 2). До того ж для досліджуваного прикладу середня абсолютна помилка для підходу на основі оптимізації становить $2,45 \%$, а для наближеного підходу $2,65 \%$.

Висновки за результатами дослідження. Таким чином, можна дійти висновку, що запропонований метод дає змогу оцінювавання спектру сигналу 3 досить високою точністю навіть на основі обмеженого обсягу даних.

Багато в чому точність підходу залежатиме від багатьох параметрів алгоритму обробки сигналу, зокрема, від умов дискретизації сигналу, обумовлених у реальних пристроях роботою аналого-цифрових перетворювачів, параметрів алгоритму побудови функції поведінки та ідентифікації метасистеми, вибору вікна для формування рівняння балансу, коефіцієнта посилення нечіткого фільтра та інших параметрів. 


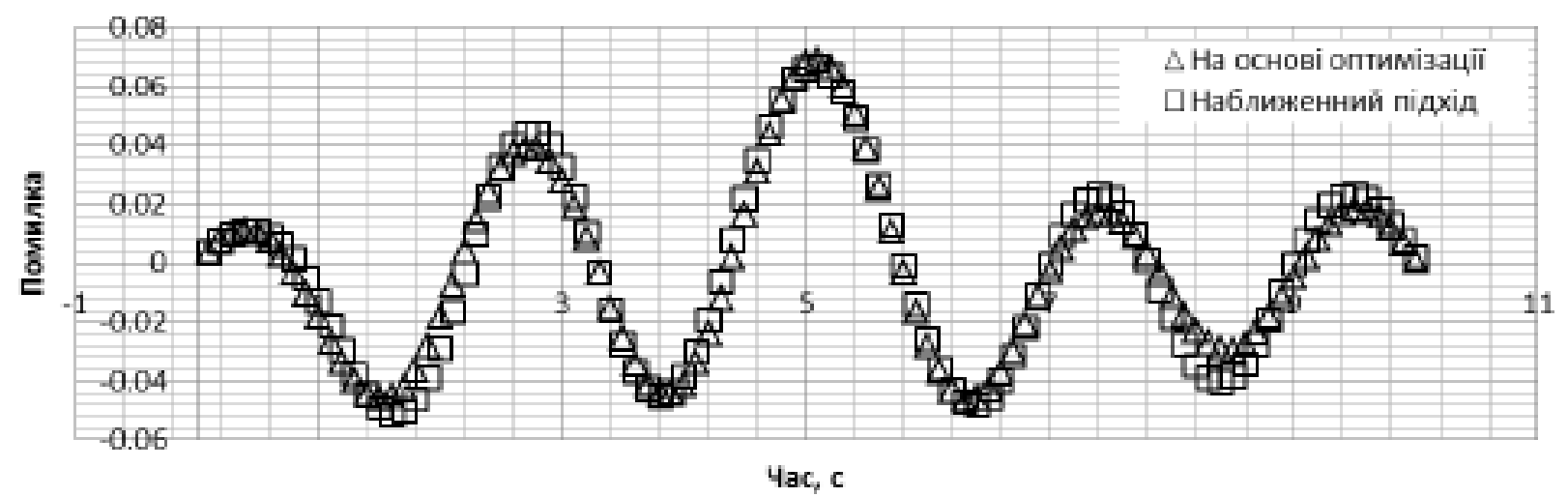

Рис. 8. Графіки помилки відновлених часових рядів за отриманими спектрами

Ці параметри $\epsilon$ параметрами налаштування алгоритму частотно-часового аналізу сигналів на основі запропонованого методу. Дослідження показали, що в разі розгляду сигналів, що мають високочастотні складові, доцільно знижувати поріг відсікання під час ідентифікації метасистеми. Необхідність виявлення нестаціонарного спектра сигналу $\epsilon$ підвищення коефіцієнта посилення нечіткого фільтра. Аналіз алгоритму показав і інші можливості його налаштування, що дає змогу підвищити ефективність запропонованого методу частотно-часового аналізу сигналів.

\section{СПИСОК ВИКОРИСТАНОЇ ЛІТЕРАТУРИ}

1. Бочарніков В. П. Частотно-часовий аналіз сигналів на основі функцій поведінки i арифметичних рядів. Частина 1. Аналіз підходів та опис методу. Збірник наукових праць Центру воєнно-стратегічних досліджень Національного університету оборони
України имені Івана Черняховського. № 3 (64). 2018.

2. Каток С. Б. Р-адический анализ в сравнении с вещественным / Пер. с англ. П. А. Колгушкина. М. МЦНМО, 2004. $112 \mathrm{c}$

3. Klir G. Elias D. (1985) Architecture of Systems Problem Solving. New York, Plenum Press, 354 p.

4. Higashi M., Klir J. Measure of uncertainty and information based of possibility distribution. International Journal of General System, 9, No.1, 1983. P. 43-58

5. Comstock F, Uyttenbove H. J. A system approach to grading of flight symulator students. Journal of Aircraft, 16, № 11, 1979. P. 780-786.

6. Bocharnikov V., Bocharnikov I. Discrete fuzzy filter of UAV's flight parameters. ISSN 1813-1166. Proceedings of the NAU, 2010. № 3. P. 30-39.

7. Bocharnikov V., Bocharnikov I. Optimal discrete fuzzy filter of UAV's flight parameters. ISSN 1813-1166. Proceedings of the NAU. 2012. № 2. P. 22-29.

8. Деза Е. И. Деза М. М. Энциклопедический словарь расстояний/ Елена Деза, Мишель-Мари Деза; Пер. с англ. Моск. гос. пед. ун-т; Нормальная высш. шк., Париж. - М.: Наука, 2008. 444 с.

\section{Стаття надійшла до редакційної колегії 18.10.2018}

\section{Бочарников В. П., Д.Т.н., профессор}

Центр военно-стратегических исследований Национального университета обороны Украины имени Ивана Черняховского, Киев

Частотно-временной анализ сигналов на основе функций поведения и арифметических рядов: исследование работоспособности метода

Резюме. В статье рассматриваются результаты исследований работоспособности нового метода частотновременного анализа дискретных сигналов, которые представлены временными рядами. Для оценки рассматривается модельный сигнал, сформированный в виде суммы синусоидальных функций с известными частотами. В результате использования метода получаются оценки спектра. Оценивается точность полученных оценок спектра, а также точность восстановления сигнала на основе этого спектра для модельного сигнала. Приведены выводы и рекомендации по применению метода для частотно-временного анализа сигналов.

Ключевые слова: временной ряд; частотно-временной анализ; p-адичные числа; функции поведения систем; системный анализ; идентификация; арифметические ряды; частотные спектры.

\section{Bocharnikov, DsT, professor}

Center for Military and Strategic Studies of the National Defence University of Ukraine named after Ivan Cherniakhovskyi, Kyiv

Time-frequency analysis of signals based on behavioral functions and arithmetic series: study of the workability of the method

Resume. The article discusses the results of studies of the performance of the new method of time-frequency analysis of discrete signals, which are represented by time series. For evaluation, a model signal is considered that is formed as a sum of sinusoidal functions with known frequencies. As a result of using the method, spectrum estimates are obtained. The accuracy of the obtained spectrum estimates is estimated, as well as the accuracy of signal recovery based on this spectrum for the model signal. The conclusions and recommendations on the application of the method for time-frequency signal analysis are given.

Keywords: time series; time-frequency analysis; p-adic numbers; system behavior functions; system analysis; identification; arithmetic series; frequency spectra. 